DOI 10.12737/article_5db94fa6d589c6.74857948

633.14:632.4
БУРАЯ РЖАВЧИНА РЖИ: АНАЛИЗ МНОГОЛЕТНЕЙ ДИНАМИКИ И ИСТОЧНИКИ УСТОЙЧИВОСТИ
Пономарева М.Л., Пономарев С.Н., Маннапова Г.С., Илалова Л.В., Гильмуллина Л.Ф., Фомин С.И.

\begin{abstract}
Реферат. Цель работы - оценить распространенность и развитие бурой ржавчины ржи во времени, определить ее вредоносность на современных сортах и выделить источники устойчивости для дальнейшей селекции. Основные учеты и исследования посевов и возбудителя (Puccinia recondita f. sp. secalis) проводили в период 2001-2017 гг. на центральной экспериментальной базе ФИЦ КазНЦ РАН (Лаишевский район Республики Татарстан). В качестве материала для исследований использовали 70 коллекционных сортообразцов озимой ржи, а также районированные и проходившие государственные сортоиспытания сорта. Анализ многолетней динамики бурой ржавчины в Республике Татарстан показал нарастание распространенности и степени развития болезни в последнее десятилетие по сравнению с предыдущим. Из 17 лет в течение пяти $(29,4 \%$ лет) заболевание принимало характер эпифитотии, имея распространенность $\geq 20 \%$. За исследуемый период развитию болезни свойственно чередование возрастания и убывания развития патогена. В результате поражения бурой ржавчиной большей степени снижалась кустистость растений (до 38\%), масса зерна с колоса (до 32\%) и с растения (до 42\%). Необходим постоянный контроль фитосанитарной обстановки и ограничение вредоносности бурой ржавчины путем создания устойчивых сортов. В результате проведенных исследований подобран генофонд из 11 российских и зарубежных сортов озимой ржи, обладающих высокой и средней устойчивостью к листовой ржавчине, которые представляют практический интерес для селекции.
\end{abstract}

Ключевые слова: озимая рожь, патоген, бурая ржавчина, распространенность, степень развития, вредоносность, устойчивость, источник.

Введение. Возбудитель бурой или листовой ржавчин ржи (Puccinia dispersa Erikss. et Henning (синоним Puccinia recondita Rob.ex Desm. f. sp. secalis) - один из самых распространенных аэрогенных фитопатогенов, который регулярно появляется во всех странах и зонах возделывания культуры [1]. В Республике Татарстан бурая ржавчина регистрируется почти ежегодно, чему способствуют высокая концентрация посевов колосовых культур и благоприятные погодные условия региона, которые предрасполагают к частым и вредоносным вспышкам болезней.

Листовые заболевания при оптимальных условиях среды для развития и заражения способны в короткий промежуток времени охватить значительную площадь посевов и вызвать эпифитотии. Более или менее значительные эпифитотии бурой ржавчины, приносящие ущерб урожаю зерна озимой ржи, случаются через 3-5 лет [2]. Снижение продуктивности растений в результате поражения этим патогеном происходит за счет уменьшения кущения, массы зерна с колоса и с растения. В меньшей степени страдает озерненность колоса и масса 1000 зерен. Потери урожая каждого растения при максимальном поражении бурой ржавчиной колеблются от 42 до $56 \%$ [3].

Пластичность возбудителя бурой ржавчины ржи (Р. recondita f. sp. secalis), способность давать несколько уредогенераций за вегетационный период, огромная скорость нарастания инфекции - все это обуславливает высокую вредоносность заболевания [4]. Доля инфекции в патогенном комплексе листового аппарата составляет 67\%. В годы эпифитотий поражение достигает $60-80 \%$, потери урожая составляют 20-25\%. По данным Чайкина В.В. (2017), в такие годы недобор урожая на посевах короткостебельных восприимчивых форм озимой ржи от поражения бурой ржавчиной достигает 50 \%, а на длинностебельных - одной трети. Отмечается, что общая вредоносность патогена в отдельные годы может превышать ущерб, причиняемый возбудителем стеблевой ржавчины вследствие его адаптивности к широкому спектру агроэкологических условий, способности распространяться на больших площадях в течение короткого времени.

Устойчивость может контролироваться как количественно, так и качественно. Эффективную и длительную устойчивость растений к листовым грибным болезням гарантирует только создание сортов, имеющих расоспецифическую и неспецифическую устойчивость. Наряду с этим, этот подход постоянно сопряжен с выявлением вредоносности болезни и с поиском новых генов устойчивости, обеспечивающих сопротивляемость к болезням.

Селекция на устойчивость к листовым инфекциям интегрирована в селекционные программы практически всех селекционных учреждений страны. Разработана методология создания сортов, длительно сохраняющих устойчивость, включающая три возможных направления: создание популяций с моногенной устойчивостью к одной или нескольким болезням, создание популяций с полигенной устойчивостью к одной или нескольким болезням и создание популяций, сочетающих различные типы устойчивости [5].

Продолжительность использования сортов в производстве ограничивается появлением новых биотипов ржавчины, исключение составляют сорта с долговременной устойчивостью. В некоторых старых популяциях ржи существуют отдельные биотипы растений, сохранившие моногенную устойчивость к листовой и стеблевой ржавчине в течение 80-130 и более лет. Долговременную эффективность проявляют гены устойчивости растений в по- 
пуляциях многолетнего дикорастущего вида Secale montanum Guss. ssp. kuprijanovii (Grossh.) Tvel. (ген Lr5), а также сортов озимой ржи Abruzzi, Lovaszpatonai (ген Lr8), Авангард, Казанская 5+6, Волжанка, Новозыбковская 4 (ген $L r 7$ ). Долговременную устойчивость к бурой ржавчине (более 140 лет) обеспечивает ген Lr4, выявленный в первом селекционном сорте Сангасте. Использование в селекции «древних», эволюционно непреодоленных генов делает возможным создание сортов, длительно сохраняющих резистентность к болезням [6]. Тем не менее, долгосрочный успех использования моногенной расоспецифической устойчивости зависит от структуры и динамики популяций листовой ржавчины [7]. Чем большие площади занимает сорт, тем быстрее он отбирает на себя вирулентную компоненту популяции и быстрее теряет устойчивость [8]. Внедряемые в производство сорта должны обладать разными типами и генами устойчивости, способными снижать численность вредного организма. При этом надо исходить из того обстоятельства, что на практике на посевах озимой ржи встречается несколько возбудителей болезней, которые в комплексе могут вызвать значительные потери и при средних уровнях развития.

Цель исследования - оценить распространенность и развитие бурой ржавчины ржи во времени, определить ее вредоносность на современных сортах и выделить источники устойчивости для дальнейшей селекции.

Условия, материалы и методы исследований. Объектами исследований служили 70 коллекционных сортообразцов озимой ржи, а также районированные и проходившие государственные сортоиспытания сорта. Основные учеты и исследования посевов и возбудителя (Puccinia recondita f. sp. secalis) проводили в период 2001-2017 гг. на центральной экспериментальной базе ФИЦ КазНЦ РАН (Лаишевский район Республики Татарстан).

Период проведения исследований охватил все многообразие гидротермических условий лесостепи Среднего Поволжья (ГТК 0,3-1,4), в т.ч. годы, близкие к норме, с недостаточным увлажнением, острозасушливые и влажные.

Данные собственных наблюдений были дополнены результатами фитосанитарного мониторинга по территории Республики Татарстан, выполненного специалистами филиала ФГБУ «Россельхозцентр». Для оценки поражения озимой ржи бурой ржавчиной использованы следующие показатели [9]:

Средневзвешенный процент распространенности (СПР):

$$
\mathrm{P}_{\mathrm{cB}}=\Sigma(\mathrm{S} * \mathrm{P}) / \mathrm{S}_{\text {обслл., }}
$$

где $\mathrm{P}_{\mathrm{cB}}-$ средневзвешенная распространенность болезни, \%;

$\Sigma(\mathrm{S} * \mathrm{P})$ - сумма произведений площадей (S) на соответствующую распространенность;

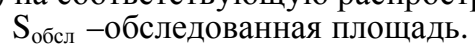

Средневзвешенная интенсивность развития (СИР) болезни:

$$
\mathrm{R}_{\mathrm{cв}}=\Sigma(\mathrm{S} * \mathrm{R}) / \mathrm{S}_{\text {обсл., }}
$$

где $\mathrm{R}_{\mathrm{cв}}$ - средневзвешенная интенсивность развития болезни, \% или балл;

$\Sigma(\mathrm{S} * \mathrm{R})$ - сумма произведений площадей
(S) на соответствующий процент или балл развития болезни;

$\mathrm{S}_{\text {обсл }}$ - обследованная площадь.

Средневзвешенные значения интенсивности развития или распространенности ржавчины более объективно учитывают складывающуюся фитосанитарную обстановку на территории, чем оценки на селекционных посевах. Это связано с тем, что при их определении учитывается обследованная площадь и доля посевов с конкретной степенью поражения.

Вредоносность бурой ржавчины определена на четырех сортах собственной селекции (Татарская 1, Эстафета Татарстана, Радонь и Огонек) в 2011-2013 гг. Для этого на делянках конкурсного сортоиспытания (площадь $20 \mathrm{~m}^{2}$ ) указанных сортов отобраны и этикетированы по 50 растений без признаков поражения (балл 0) и 50 восприимчивых (балл 4) в трех полевых повторениях. В качестве контроля использовали растения с 0 баллом поражения. Альтернативные по устойчивости растения проанализированы по урожайобразующим признакам. Учет болезни - однократный в период ее наибольшего развития (фаза молочной спелости зерна).

При оценке устойчивости коллекционного генофонда и сортов конкурсного сортоиспытания озимой ржи использовали следующие оценки:

Тип реакции на поражение бурой ржавчиной определяли по шкале Mains и Jackson [10], где устойчивыми к заболеванию считали растения с типами реакций $0 ; 1$ и 2 балла, а восприимчивыми - растения с типами реакций 3 и 4 балла.

Степень поражения листовой ржавчиной определяли по шкале [1].

Распространенность болезни (\%) вычислена по формуле:

$$
\mathrm{P}=100 \mathrm{n} / \mathrm{N},
$$

где $\mathrm{P}$ - распространенность болезни;

$\mathrm{n}$ - количество больных растений в образце;

$\mathrm{N}$ - общее количество растений (больных и здоровых) в образце.

Степень развития болезни вычислялась как средняя интенсивность поражения (для каждого сорта в \%) по формуле:

$$
\mathrm{C}=\left(\sum(\mathrm{a} \times \mathrm{b}) \div(\mathrm{N} \times \mathrm{K})\right) \times 100 \%,
$$

где $\sum(\mathrm{a} \times \mathrm{b})$ - сумма произведений количества больных растений (a) на соответствующий им балл поражения (b);

$\mathrm{N}$ - количество проанализированных растений,

K - высший балл шкалы учета.

Анализ и обсуждение результатов. Наши исследования, основанные на результатах собственного мониторинга и данных фитосанитарных обзоров филиала ФГБУ «Россельхозцентра» по Республике Татарстан, за период с 2001 по 2017 годы приведены на рисунке 1 . Они показали, что из 17 лет экономически значимого уровня распространенности (20\% и более) бурая ржавчина достигла в вегетационном периоде 2007 г. и за период с 2011 по 2014 годы, когда средневзвешенный процент распространения болезни превышал указанную величину и варьировал от 20 до 


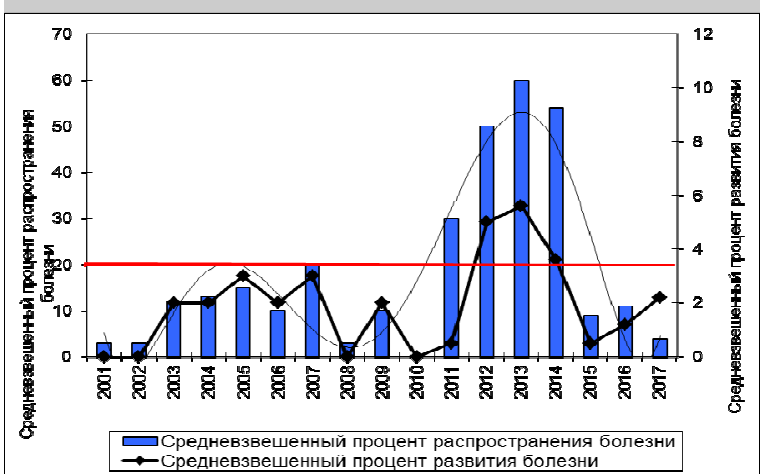

Рисунок 1 - Распространенность и интенсивность бурой ржавчины на посевах озимой ржи в Республике Татарстан (\%), 2001-2017 гг.

$60 \%$.

Регрессионный анализ подтвердил полиномиальную модель ( $\mathrm{y}=0,0014 \mathrm{x}^{6}-0,0733 \mathrm{x}^{5}+$ $\left.1,4564 \mathrm{x}^{4}-13,57 \mathrm{x}^{3}+60,124 \mathrm{x}^{2}-111,85 \mathrm{x}+69,14\right)$ развития эпифитотии Puccinia dispersa Eriks. et Henn. на территории республики, для которой свойственны переменные возрастания и убывания. Значение $\mathrm{R}^{2}=0,8146$, что свидетельствует о хорошем совпадении расчетной линии с опытными данными. Степень полинома, равная 6, определяет количество экстремумов (максимумов и минимумов) кривой. Максимальное распространение листовой ржавчины (более 50\%) отмечалось в 2012-2014 гг. В крайне засушливом 2010 году наблюдалась практически полная депрессия в развитии этого грибного патогена.

Методы мониторинга состояния посевов развиваются с целью прогнозирования их динамики и планирования агротехнологических мероприятий для управления состоянием растений в посевах, в том числе при развитии грибной инфекции [11]. Сравнивая полученные нами результаты с анализом Агроэкологического атласа России, приходим к выводу, что Республика Татарстан на дату его составления входила в зону со средней вредоносностью по бурой ржавчине (рисунок 2). Наши исследования показали, что распространенность этой инфекции за последние годы заметно возросла, а ее негативное влияние начинает ощущаться в более ранние стадии, иногда даже период в осенней вегетации. Так, если за первые 10 лет изучаемого периода СПР = $8,9 \%$, а СИР $=1,4 \%$, то за последние 7 лет эти показатели составили $31,1 \%$ и 2,6\%, соответственно. Возможно это обусловлено погодными условиями, благоприятствующими патоге-

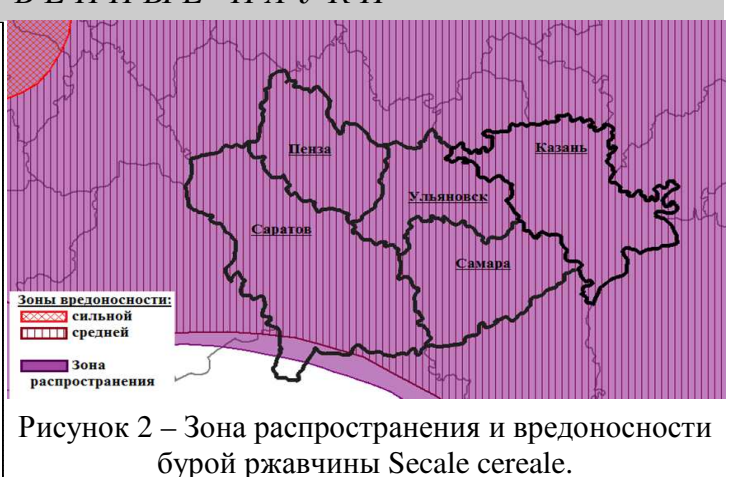

бурой ржавчины Secale cereale.

Афонин А.Н., Грин С.Л., Дзюбенко Н.И., Фролов А.Н. Агроэкологический атлас России и сопредельных государств: экономически значимые растения, их вредители, болезни и сорные растения [Интернет-версия 2.0]. 2008. http:// www.agroatlas.ru/en/content/related

незу заболевания, но при этом не следует отрицать и недостаточную генетическую устойчивость возделываемых сортов.

Представленные результаты привели нас к необходимости анализа потерь урожайности у растений с контрастным уровнем устойчивости к болезням (табл.1). Развитие болезни отрицательно сказывалось на формировании отдельных элементов продуктивности, что впоследствии ограничивало урожайность. Сравнение устойчивых (балл 0) и восприимчивых растений (балл 4) показало, что в большей степени в результате поражения бурой ржавчиной снижалась кустистость растений (32... $37,8 \%$ ), масса зерна с колоса $(23,7 \ldots 32,3 \%)$, масса зерна с растения $(31,6 \ldots 41,9 \%)$ в зависимости от генотипа сорта. Продуктивность колоса снижалась за счет уменьшения количества зерен в колосе на $12 . .23,6 \%$ и массы 1000 зерен на 6,7..22\%. У сорта Татарская 1 отмечено наибольшее влияние бурой ржавчины на продуктивную кустистость, массу зерна с колоса и крупность зерна. Сорт Эстафета Татарстана под влиянием патогена в наибольшей степени снижал высоту растений и длину главного колоса, тогда как у сорта Огонек выявлено уменьшение озерненности колоса и продуктивности растения (табл.1).

При сравнении изменений элементов структуры урожая, вызванных патогеном, было установлено, что варьирование различных показателей неодинаково. Так, наименьшая вариабельность между устойчивыми и восприимчивыми растениями наблюдается по высоте растений, длине главного колоса и количеству зерен в колосе. Снижение урожая было обусловлено уменьшением одного из элементов, или несколькими элементами структуры уро-

Таблица 1 - Вредоносность бурой ржавчины на районированных сортах озимой ржи

\begin{tabular}{|c|c|c|c|c|c|c|c|c|}
\hline Сорт & $\begin{array}{c}\text { Балл } \\
\text { пора- } \\
\text { жения }\end{array}$ & $\begin{array}{c}\text { Кродуктивная } \\
\text { кустость, } \\
\text { шт. }\end{array}$ & $\begin{array}{c}\text { Высота } \\
\text { растений, } \\
\text { см }\end{array}$ & $\begin{array}{c}\text { Длина } \\
\text { главного } \\
\text { колоса }\end{array}$ & $\begin{array}{c}\text { Число } \\
\text { зерен } \\
\text { с колоса }\end{array}$ & $\begin{array}{c}\text { Масса зерна } \\
\text { г главного } \\
\text { колоса }\end{array}$ & $\begin{array}{c}\text { Масса } \\
\text { зерна с } \\
\text { растения, г }\end{array}$ & $\begin{array}{c}\text { Масса } \\
1000 \\
\text { зерен, г }\end{array}$ \\
\hline \multirow{2}{*}{ татарская 1} & 0 & $4,5 \pm 0,4$ & $132,5 \pm 4,7$ & $8,7 \pm 0,5$ & $47,1 \pm 6,3$ & $1,98 \pm 0,20$ & $6,01 \pm 1,04$ & $38,7 \pm 3,3$ \\
\cline { 2 - 9 } & 4 & $2,8 \pm 0,2$ & $125,4 \pm 4,1$ & $8,4 \pm 0,8$ & $38,0 \pm 4,9$ & $1,34 \pm 0,18$ & $4,11 \pm 0,61$ & $30,2 \pm 1,7$ \\
\hline Эстафета & 0 & $4,7 \pm 0,2$ & $133,3 \pm 4,5$ & $10,2 \pm 0,4$ & $57,6 \pm 3,4$ & $2,60 \pm 0,20$ & $8,28 \pm 0,87$ & $41,8 \pm 1,3$ \\
\cline { 2 - 9 } Татарстана & 4 & $3,0 \pm 0,2$ & $118,2 \pm 5,0$ & $9,8 \pm 0,5$ & $50,7 \pm 4,0$ & $1,82 \pm 0,12$ & $5,15 \pm 0,45$ & $36,0 \pm 2,7$ \\
\hline Радонь & 0 & $5,2 \pm 0,4$ & $138,0 \pm 3,6$ & $10,6 \pm 0,1$ & $54,5 \pm 3,1$ & $2,18 \pm 0,18$ & $6,32 \pm 1,02$ & $39,4 \pm 1,6$ \\
\cline { 2 - 9 } & 4 & $3,4 \pm 0,2$ & $120,1 \pm 8,1$ & $9,9 \pm 0,3$ & $42,0 \pm 4,4$ & $1,55 \pm 0,14$ & $4,17 \pm 0,43$ & $36,7 \pm 1,6$ \\
\hline Огонек & 0 & $4,7 \pm 0,3$ & $130,6 \pm 3,0$ & $9,0 \pm 0,3$ & $40,4 \pm 2,9$ & $1,73 \pm 0,13$ & $5,90 \pm 0,60$ & $43,5 \pm 1,7$ \\
\cline { 2 - 9 } & 4 & $3,2 \pm 0,2$ & $123,0 \pm 3,1$ & $8,6 \pm 0,6$ & $31,0 \pm 5,1$ & $1,32 \pm 0,20$ & $3,43 \pm 0,31$ & $39,0 \pm 1,8$ \\
\hline
\end{tabular}


СЕ ЛЬСКОХОЗ ЯЙСТВЕННЫЕ НАУКИ

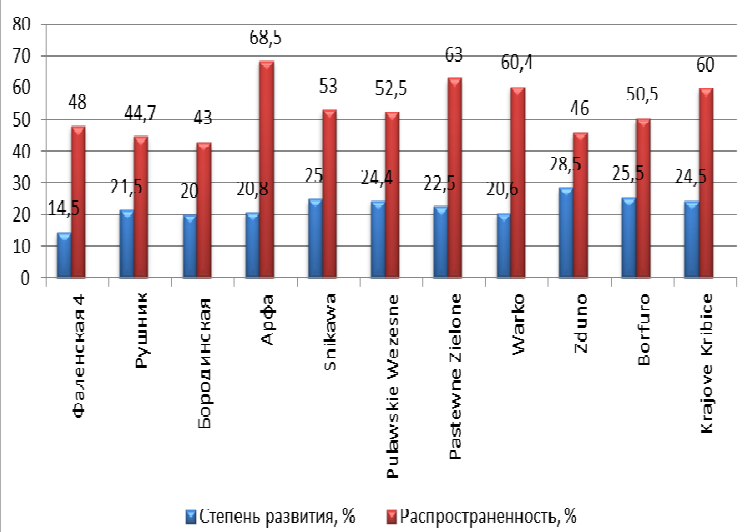

Рисунок 3 - Регионально адаптированный генофонд источников устойчивости к бурой ржавчине (искусственный инфекционный фон)

жая. Полученные данные подтверждают необходимость выявления и создания источников устойчивости к листовой ржавчине и проведение направленных скрещиваний с ними. К источникам устойчивости мы относили те генотипы, которые сохраняют признак устойчивости в течение не менее трех лет изучения на инфекционных фонах. Создание источников проводили путем индивидуального отбора элитных растений при искусственном заражении возбудителем бурой ржавчины.

При использовании отечественных и зарубежных источников устойчивости создан регионально адаптированный исходный материал для селекции устойчивых к листовой ржавчине сортов (рисунок 3). В условиях искусственного заражения и естественного развития инфекции представленные образцы превышали стандартный сорт Радонь, у которого степень развития бурой ржавчиной в те же годы составляла $31 \%$, а распространенность $-80 \%$. При этом следует отметить, что высокоустойчивых источников (степень развития $\leq 10 \%$ ) не обнаружено.

Выявлено лишь два устойчивых российских сорта Фаленская 4 и Бородинская (степень развития болезни 11-20\%), у которых показатель составил 14 и 20\%, соответственно. Приближались к ним по устойчивости Арфа (Украина), Warko (Польша) и Рушник (Россия). Иностранные образцы Pastewne Zielone, Palonskie Wczeshe, Krajove Kribice, Zduno (Польша), Borfuro (Германия), Snikawa (Финляндия) имели степень развития бурой ржавчины за годы исследований в пределах от 22 до 30\%, что позволяет их отнести к среднеустойчивым сортам. Отсутствие устойчивых сортообразцов осложняет селекционную работу по ускоренному созданию устойчивых сортов. Данные сорта включены в селекционный процесс с целью получения рекомбинантов, объединяющих гены устойчивости, выносливости и адаптивности местных сортов с их генами.

Выводы. Таким образом, анализ многолетней динамики бурой ржавчины в Республике Татарстан показал нарастание распространенности и степени развития болезни в последнее десятилетие по сравнению с предыдущим. Из 17 лет в течение пяти $(29,4 \%$ лет) заболевание принимало характер эпифитотии, имея распространенность $\geq 20 \%$. За исследуемый период развитию болезни согласно полиномиальной модели свойственно чередование (с шестью экстремумами) возрастания и убывания развития патогена. В результате поражения бурой ржавчиной большей степени снижалась кустистость растений (до 38\%), масса зерна с колоса (до $32 \%$ ) и с растения (до 42\%). Поэтому необходим постоянный контроль фитосанитарной обстановки и ограничение вредоносности бурой ржавчины, в т.ч. и селекционными методами, путем создания устойчивых сортов. Наряду с этим, нужно учитывать, что для снижения скорости роста численности листовой ржавчины, внедряемые в производство сорта озимой ржи должны обладать разными типами и генами устойчивости.

В результате проведенных исследований подобран генофонд из 11 российских и зарубежных сортов озимой ржи, обладающих высокой и средней устойчивостью к листовой ржавчине, которые представляют практический интерес для селекции.

Литература

1. Miedaner, T. Effect of leaf rust on yield components of winter rye hybrids and assessment of quantitative resistance / T. Miedaner, U. Sperling // J.Phytopathol. 1995. V.143. № 11/12. P. 725-730.

2. Кадырова Ф. З., Пономарева М.Л., Пономарев С.Н. Проявление признаков продуктивности и экологической устойчивости у новых сортов озимой ржи и гречихи. // Доклады Российской академии сельскохозяйственных наук. №4, 2000. С. 6-8.

3. Пономарева М.Л., Пономарев С.Н., Якупова Г.Г., Маннапова Г.С. Потери урожая озимой ржи от комплекса грибных болезней // Владимирский земледелец. 2011. № 2. С. 22-26.

4. Пономарева М.Л., Пономарев С.Н. Селекционная ценность источников устойчивости озимой ржи к группе грибных болезей // Вестник защиты растений. №1. 2000. С. 59-64.

5. Солодухина О.В., Кобылянский В.Д. Принципы стратегии селекции сортов озимой ржи на долговременную устойчивость к грибным болезням // Труды по прикладной ботанике, генетике и селекции. 2011. Т. 168. C. 79-89.

6. Кобылянский В.Д. Солодухина О.В. Вредоносность патогенов ржавчины и мучнистой росы на озимой ржи и стратегия селекции болезнеустойчивых сортов // Идентифицированный генофонд растений и селекция. СПб.: ВНИИР, 2005. С. 572-591.

7. Miedaner T. Klocke B., Flath K., Geiger H.H., Weber W.E. Diversity, spatial variation, and temporal dynamics of virulence in the German leaf rust (Puccinia recondite f. sp. secalis) population in winter rye // European Journal of Plant Pathology. 2012. V. 132, I. 1, pp 23-35.

8. Крупнов В.А. Стратегия генетической защиты пшеницы от листовой ржавчины в Поволжье // Вестник PACXH. 1997. № 6. C. 12-15.

9. Болезни зерновых колосовых культур (рекомендации по проведению фитосанитарного мониторинга): научное издание под ред. С.С.Санина - М., ФГНУ «Росинформагротех», 2010. $140 \mathrm{c.}$

10. Mains, E.B. Physiologic specialization in leaf rust of wheat (Puccinia triticina Erikss.) / E.B. Mains, H.S. 
Jackson // Phytopathology. 1926. V. 16. P. 89-120.

11. Николаев С.В., Зубаирова У.С., Сколотнева Е.С., Орлова Е.А., Афонников Д.А. Системный подход к моделированию развития листостебельных грибных инфекций пшеницы. Вавиловский журнал генетики и селекции. 2019;23(1):100-109. DOI 10.18699/VJ19.468A.

Сведения об авторах:

Пономарева Мира Леонидовна - доктор биологических наук, профессор, главный научный сотрудник, заведующий отделом селекции озимых культур, e-mail: smponomarev@yandex.ru

Пономарев Сергей Николаевич - доктор сельскохозяйственных наук, главный научный сотрудник отдела, e-mail: smponomarev@yandex.ru

Маннапова Гульназ Сулеймановна - кандидат сельскохозяйственных наук, старший научный сотрудник, e-mail: mgs1980@mail.ru

Гильмуллина Лилия Фирдависовна - кандидат сельскохозяйственных наук, старший научный сотрудник, e-mail: lilya-muslima@mail.ru.

Фомин Сергей Иванович - кандидат сельскохозяйственных наук, старший научный сотрудник

Илалова Любовь Валентиновна - научный сотрудник, e-mail: love_bulkina@mail.ru.

Татарский научно-исследовательский институт сельского хозяйства ФИЦ Казанский научный центр РАН, г. Казань, Россия

\section{BROWN RUST OF RYE: ANALYSIS OF LONG-TERM DYNAMICS AND SUSTAINABILITY SOURCES} Ponomareva M.L., Ponomarev S.N., Mannapova G.S., Ilalova L.V., Gilmullina L.F., Fomin S.I.

Abstract. The purpose of the work is to assess the prevalence and development of rye brown rust over time, to determine its harmfulness in modern varieties and to identify sources of resistance for further selection. The main counts and studies of crops and the pathogen (Puccinia recondita f. sp. secalis) were carried out in the period 2001-2017 at the central experimental field of "KazSC RAS" (Laishevsky district of the Republic of Tatarstan). As a material for research, 70 collection varieties of winter rye were used, as well as zoned and passed state varietal tests of the variety. An analysis of the longterm dynamics of brown rust in the Republic of Tatarstan showed an increase in the prevalence and degree of development of the disease in the last decade compared to the previous one. Out of 17 years, for five $(29.4 \%$ of years) the disease assumed the character of epiphytotia, with a prevalence of $\geq 20 \%$. During the study period, the development of the disease is characterized by an alternation of increase and decrease in the development of the pathogen. As a result of brown rust damage, bushiness of plants decreased to a greater extent (up to 38\%), grain weight from an ear (up to $32 \%$ ) and from a plant (up to $42 \%$ ). Constant monitoring of the phytosanitary situation and limitation of the harmfulness of brown rust by creating resistant varieties are required. As a result of the research, a gene pool was selected from 11 Russian and foreign winter rye varieties that have high and medium resistance to leaf rust, which are of practical interest for selection.

Key words: winter rye, pathogen, brown rust, prevalence, degree of development, harmfulness, resistance, source.

\section{References}

1. Miedaner, T. Effect of leaf rust on yield components of winter rye hybrids and assessment of quantitative resistance / T. Miedaner, U. Sperling // J.Phytopathol. 1995. V.143. № 11/12. P. 725-730.

2. Kadyrova F. Z., Ponomareva M.L., Ponomarev S.N. Proyavlenie priznakov produktivnosti i ekologicheskoy ustoychivosti u novykh sortov ozimoy rzhi i grechikhi. I/ Doklady Rossiyskoy akademii selskokhozyaystvennykh nauk. (Manifestation of signs of productivity and environmental sustainability in new varieties of winter rye and buckwheat. // Reports of the Russian Academy of Agricultural Sciences). №4 2000. P. 6-8.

3. Ponomareva M.L., Ponomarev S.N., Yakupova G.G., Mannapova G.S. Losses of winter rye harvest from a complex of fungal diseases. [Poteri urozhaya ozimoy rzhi ot kompleksa gribnykh bolezney]. // Vladimirskiy zemledelets. - Vladimir farmer. 2011. № 2. P. 22-26.

4. Ponomareva M.L., Ponomarev S.N. The breeding value of resistance sources of winter rye to the group of fungal diseases. [Selektsionnaya tsennost istochnikov ustoychivosti ozimoy rzhi k gruppe gribnykh bolezey]. // Vestnik zashchity rasteniy. - The herald of plant protection. №1. 2000. P. 59-64.

5. Solodukhina O.V., Kobylyanskiy V.D. The principles of the strategy for breeding of winter rye varieties for longterm resistance to fungal diseases. // Trudy po prikladnoy botanike, genetike i selektsii. [Printsipy strategii selektsii sortov ozimoy rzhi na dolgovremennuyu ustoychivost k gribnym boleznyam. // Scietific articles on Applied Botany, Genetics and Selection]. 2011. Vol. 168. P. 79-89.

6. Kobylyanskiy V.D. Solodukhina O.V. Vredonosnost patogenov rzhavchiny i muchnistoy rosy na ozimoy rzhi i strategiva selektsii bolezneustoychivykh sortov. I/ Identifitsirovannyy genofond rasteniy i selektsiya. [The harmfulness of pathogens of rust and powdery mildew in winter rye and the strategy of selection of disease-resistant varieties. // Identified plant gene pool and selection]. - SPb.: VNIIR, 2005. P. 572-591.

7. Miedaner T. Klocke B., Flath K., Geiger H.H., Weber W.E. Diversity, spatial variation, and temporal dynamics of virulence in the German leaf rust (Puccinia recondite f. sp. secalis) population in winter rye // European Journal of Plant Pathology. 2012. V. 132, I. 1, P. 23-35.

8. Krupnov V.A. The genetic protection strategy for wheat from leaf rust in the Volga region. [Strategiya geneticheskoy zaschity pshenitsy ot listovoy rzhavchiny v Povolzhe]. // Vestnik RASKhN. - The Herald of RAAS. 1997. № 6. P. 12-15.

9. Bolezni zernovykh kolosovykh kultur (rekomendatsii po provedeniyu fitosanitarnogo monitoringa): nauchnoe izdanie pod red. S.S.Sanina. [Diseases of cereal crops (recommendations for phytosanitary monitoring): scientific publication, edited by S.S. Sanin] - M., FGNU "Rosinformagrotekh", 2010. P. 140.

10. Mains E.B. Physiologic specialization in leaf rust of wheat (Puccinia triticina Erikss.) / E.B. Mains, H.S. Jackson // Phytopathology. 1926. V. 16. P. 89-120.

11. Nikolaev S.V., Zubairova U.S., Skolotneva E.S., Orlova E.A., Afonnikov D.A. A systematic approach to modeling the development of leafy fungal infections of wheat. [Sistemnyy podkhod $\mathrm{k}$ modelirovaniyu razvitiya listostebelnykh gribnykh infektsiy pshenitsy]. Vavilovskiy zhurnal genetiki i selektsii. - Vavilov Journal of Genetics and Breeding. 2019; 23 (1): 100-109. DOI 10.18699/VJ19.468A.

Authors:

Ponomareva Mira Leonidovna - Doctor of Biological sciences, Professor, chief researcher, Head of Winter crop breeding Department, e-mail: smponomarev@yandex.ru

Ponomarev Sergey Nikolaevich - Doctor of Agricultural sciences, chief researcher, Winter crop breeding Department, email: smponomarev@yandex.ru

Mannapova Gulnaz Suleymanovna - Ph.D. of Agricultural sciences, senior researcher of Winter crop breeding Department, e-mail:mgs1980@mail.ru

Gilmullina Liliya Firdavisovna - Ph.D. of Agricultural sciences, senior researcher of Winter crop breeding Department, email: lilya-muslima@mail.ru.

Fomin Sergey Ivanovich - Ph.D. of Agricultural sciences, senior researcher of Winter crop breeding Department,

Ilalova Lyubov Valentinovna - researcher of Winter crop breeding Department, e-mail: love bulkina@mail.ru

Tatar Scientific Research Institute of Agriculture, FRC Kazan Scientific Center, Russian Academy of Sciences, Kazan, Russia. 